Article

\title{
Agricultural Practice in Poland Before and after Mandatory IPM Implementation by the European Union
}

\author{
Zuzanna Sawinska ${ }^{1}$, Stanisław Świtek ${ }^{1, *(\mathbb{D})}$, Romana Głowicka-Wołoszyn ${ }^{2}$ (1) \\ and Przemysław Łukasz Kowalczewski ${ }^{3}$ (D) \\ 1 Department of Agronomy, Poznań University of Life Sciences, 11 Dojazd St., 60-632 Poznań, Poland; \\ zuzanna.sawinska@up.poznan.pl \\ 2 Department of Finance and Accounting, Poznań University of Life Sciences, 28 Wojska Polskiego St., \\ 60-637 Poznań, Poland; roma@up.poznan.pl \\ 3 Institute of Food Technology of Plant Origin, Poznań University of Life Sciences, 31 Wojska Polskiego St., \\ 60-624 Poznań, Poland; przemyslaw.kowalczewski@up.poznan.pl \\ * Correspondence: stanislaw.switek@up.poznan.pl
}

Received: 29 December 2019; Accepted: 2 February 2020; Published: 4 February 2020

\begin{abstract}
Integrated pest management (IPM), a worldwide agricultural strategy, contains methods to control or manage agricultural pests and diseases in a more efficient way, and consequently, to obtain better quality raw materials for food production. The engagement and practice of farmers play a key role in the success of this strategy. Since January 1, 2014, Poland and other European Union countries have been obligated to apply the principles of IPM. This paper shows the results of surveys conducted in 280 randomly selected farms the year before and the year following mandatory IPM implementation. The aim of this study was to gather information about farmers' knowledge of IPM and the most commonly used plant protection methods. Our results show that law regulations do not significantly change agricultural practice. Among the non-chemical methods farmers most often comply with are: implementing the agrochemical calendar, sowing healthy material, destroying volunteer plants, rotating crop, applying balanced fertilizer, plowing stubble and preventing excess nitrogen. Integrated plant protection is not possible without proper knowledge of diseases. This factor needs improvement in Poland. The average Polish farmer lacks the knowledge about basic cereal diseases such as powdery mildew or brown rust, though larger farm operators tend to be more knowledgeable. The results of this survey demonstrate the necessity to provide informative farmer training campaigns to promote on-farm application of IPM and to improve the knowledge of disease issues.
\end{abstract}

Keywords: integrated farming; integrated pest management; farmers questionnaires; plant protection; sustainable agriculture

\section{Introduction}

Integrated Pest Management (IPM) is a strategy that encourages the reduction of pesticide use by employing a variety of nonchemical pest control methods to contain or manage pests below their economic injury levels [1]. The IPM programs implemented in various countries utilize all possible control strategies, including biological, cultural, chemical and ecosystem health techniques with the goal of reducing purchased inputs while maintaining the crop yield, its quality and profits [2-4]. The beginnings of integrated pest management took place in the United States in the 1960s as a response to the emerging environmental problems associated with the use of large amounts of chemical plant protection products [5]. Currently, IPM is the main paradigm in plant production approved by scientists, policymakers, international development agencies [6] and public opinion [7]. In recent years, 
new regulations in Europe have forced farmers to use methods other than chemical protection [8] that are more environmentally friendly $[9,10]$.

Since January 1, 2014, farmers in EU countries (including Poland as a member state) must use IPM methods in daily plant production operations, according to Directive 2009/128/EU [11]. According to the directive [12], the principles of integrated plant protection should include:

- Prevention and/or suppression of harmful organism supported by non-chemical options like crop rotation, adequate cultivation techniques, use of resistant/tolerant cultivars, use of balanced fertilization, hygiene measures, protection and enhancement of beneficial organisms;

- Harmful organism must be monitored;

- Protection measures must be based on monitoring;

- Biological, physical, and other non-chemical methods must be preferred to chemical method;

- Pesticides should be specific and have minimum side effects;

- Levels of applied intervention should be kept to a necessary minimum;

- Anti-resistant strategy should be performed;

- The success of plant protection measures should be implemented [13].

Following these guidelines, the Polish Minister of Agriculture and Rural Development introduced relevant regulations [14]. Collected in the Decree on Integrated Plant Protection, they cover all methods of plant protection against pests and focus on the use of pest controlling non-chemical methods such as:

- crop rotation with appropriate sowing dates

- agricultural technology, including mechanical operations

- adoption of pest resistant plant varieties

- application of fertilization, irrigation and liming

- cleaning and disinfection of machinery and objects that could contribute to the spread of harmful organisms

- promotion of preservation and improvement of the conditions for the development of beneficial organisms, such as pollinating insects and pests' natural enemies

Chemical plant protection products should be selected in such a way as to minimize the side effects of their use, in particular the impact on beneficial organisms. The number of treatments and the number of measures should be as small as possible. Pesticides should be selected in such a way as to prevent the resistance of harmful organisms through alternating use of active substances. According to the plan the priority action provided through Ministry of Agriculture was to disseminate knowledge to all agents involved in plant protection, such as sprayer operators, advisors, and pesticide distributors. Professional advisors were trained first before passing the knowledge onto the farmers [15]. Changes were also introduced to the education system at agricultural schools. Students acquired knowledge consistent with integrated plant protection. The knowledge transfer was conducted through specialized training, preparing and disseminating research results and building an IT platform dedicated to integrated plant protection. In addition, integrated plant protection methodologies were developed [16] with guidelines for each crop species and established economic injury levels. Some steps were already implemented during the compulsory IPM period. An example is the website dedicated to monitoring pests which started operating in 2016, two years after IPM implementation. The resistance of plant varieties to pests was recognized by the Central Research Center for Crop Varieties which publishes the results of research on individual varieties [17]. Moreover, each of the professionals had to participate in a 14- to 24-h course. Training participants were obliged to complete the course and pass a written exam, and in return, received a certificate that was valid for the next 5 years. Moreover, they were required to undergo supplementary training every 5 years. A slot of $2.5 \mathrm{~h}$ of the training was dedicated to the integrated plant protection. Regulation (EC) No 1107/2009 mandated the implementation of the integrated protection principles but the details of the implementation were left to the member states. In Poland, monitoring and control of the implementation process is carried 
out through the Integrated Pest Management system operated by the State Plant Health and Seed Inspection Service. As part of the control, the records of treatments from the current and previous years are analyzed, field cultivation control performed and samples of plants collected for analysis. Instructions are also provided to the farmers. At the beginning of the IPM rules, farmers were not penalized for their infractions and only recommendations for improvement were made. However, auditors have the right to impose a fine in cases where the regulations are grossly violated, e.g., when pollinating insects are endangered. In the sample record of plant protection treatments, the farmer must provide [18]:

- date of intervention

- the name of the plant being grown,

- field area (ha),

- the size of the surface on which the treatment was performed,

- field number,

- trade name of the measure,

- name of the active substance,

- dose per 1 ha

- the reason for using the agent, including the disease,

- weather conditions during the procedure,

- development phase 1. treatment effectiveness.

Non-chemical activities were, therefore, out of actual control, while the research presented in this paper mainly focuses on the two first principles of integrated pest management methods: prevention and suppression of harmful organisms by non-chemical means and monitoring of these organisms.

In Poland, agriculture is a significant sector of the economy. Plant production accounts for around $43 \%$ of the total agricultural production, which places Poland second in the EU in terms of arable land area [19]. Changes in Polish agriculture are continually taking place but the dynamics and direction of these changes are clearly differentiated regionally. The level and structure of agricultural production is governed, to a large extent, by climate and soil, as well as by economic and organizational conditions [20]. Implementation and adoption of IPM strategies can help reduce environmental and human health risks as well as pest management costs [21]. To successfully adopt IPM rules, appropriate awareness of farmers is crucial [22]. Correct diagnosis of plant development, plant conditions, and their relationship to diseases are the necessary farmer skills [23-25].

The aim of this paper was to explore practices and perspectives of farmers on the eve of the mandatory IPM implementation and also in the first year following its implementation.

\section{Materials and Methods}

\subsection{Study Sites}

The research was based on a survey conducted with randomly selected farms located in a major agricultural region of Poland called Greater Poland (Wielkopolska) in 2013-2014. It is worth noting that a well-developed food and dairy industry [26] are characteristic features of the Wielkopolska region. Around $60 \%$ of the total area is used for agriculture [27] where cereals such wheat (Triticum aestivum), triticale (Triticosecale) rye (Secale cereal), barley (Hordeum vulgare) and corn (Zea mays) are mainly cultivated. Among non-cereal crops, the most important are oilseed rape (Brassica napus), sugar beet (Beta vulgaris) and potato (Solanum tuberosum) [28].

A number of interviews were carried out, of which 280 (93\%) complete ones were chosen for the analysis. Incomplete questionnaires were not included in the study. The agro-industrial economy of Wielkopolska is characterized by modern farms that produce cereals and corn and also breed livestock. According to the General Agricultural Census [29], the number of farms in the region was 162.7 thousand in 2010 . Over 116 thousand had area of less than 10 ha, over 29 thousand -10 to 20 ha 
and almost 17 thousand-over 20 ha. Farmers participating in the survey represented farms of various sizes (Table 1).

Table 1. Number of farmers participating in the survey.

\begin{tabular}{ccc}
\hline Farms Area & Number of Questionnaires 2013 & Number of Questionnaires 2014 \\
\hline$<10$ ha & 47 & 34 \\
$11-20$ ha & 61 & 58 \\
$21-30$ ha & 20 & 22 \\
$>30$ ha & 22 & 16 \\
\hline
\end{tabular}

\subsection{Survey Methodology}

The survey was conducted on both large- and small-scale farms in order to determine whether the size of the cultivated area had an influence on the chosen methods of plant protection. Survey questionnaires were filled out on-site by the interviewer who accompanied the farmer. A knowledge, attitude and practices (KAP) survey was used and the standard pattern of questions was employed. The questions in first part of the survey concerned the profile of the respondents and included farm characteristics such as its size and cultivation area, type of crops, and knowledge of plant fungal diseases. In the second part of the questionnaire, the farmers were asked about the employed methods of plant protection, chemical as well as non-chemical. In addition, farmers were asked about the timing of treatments and the effectiveness of protection (defined on the basis of farm productivity and observations). The final part of the questionnaire concerned the farmers' knowledge of IPM. The survey data were analyzed in Microsoft Excel and a statistical analysis of the survey data was also performed with Statistica 13 software (Dell Software Inc., Round Rock, TX, USA). The chi-square test was used to determine differences between the survey years ( $p$-values indicated whether the data were significantly different between years). Response trends were tested using Pearson's correlation. Responses in individual years may have come from the same or different farmers.

\section{Results}

In our questionnaire, we provided farmers with 13 examples of agro-technical methods used by farmers to reduce the pressure of pests and their harmfulness and asked the farmers which methods they used on their own farm in the year before and one year after the mandatory IPM implementation. Seven of the methods were found to be popular among farmers and their use did not change after the introduction of IPM in Poland (Figure 1). The most popular included: sowing plants at the optimum agro-technical time, sowing healthy seed, destroying volunteer plants, crop rotation, balanced fertilization applications, plowing system and the prevention of nitrogen leaching. IPM-compliant methods, such as the growing of resistant varieties, spatial isolation of cultivated plants, destruction of plant bridges, early sowing and the cultivation of early varieties were less popular among farmers. There were no significant statistical differences between years for any of the methods, except for the spatial isolation of winter and spring wheat $(p<0.01)$. In the first year of IPM implementation, this method was used less frequently than a year earlier.

We assessed the importance of production scale for the application of IPM practices. Differences in the application of methods related to integrated production were visible between the farms of various sizes: the application of IPM practices increased with increasing farm size (Figure 2). In both years of the survey, the proportion of applied practices in all farm size groups $(p<0.001)$ where similar, except in farms with area of 11-20 ha. 


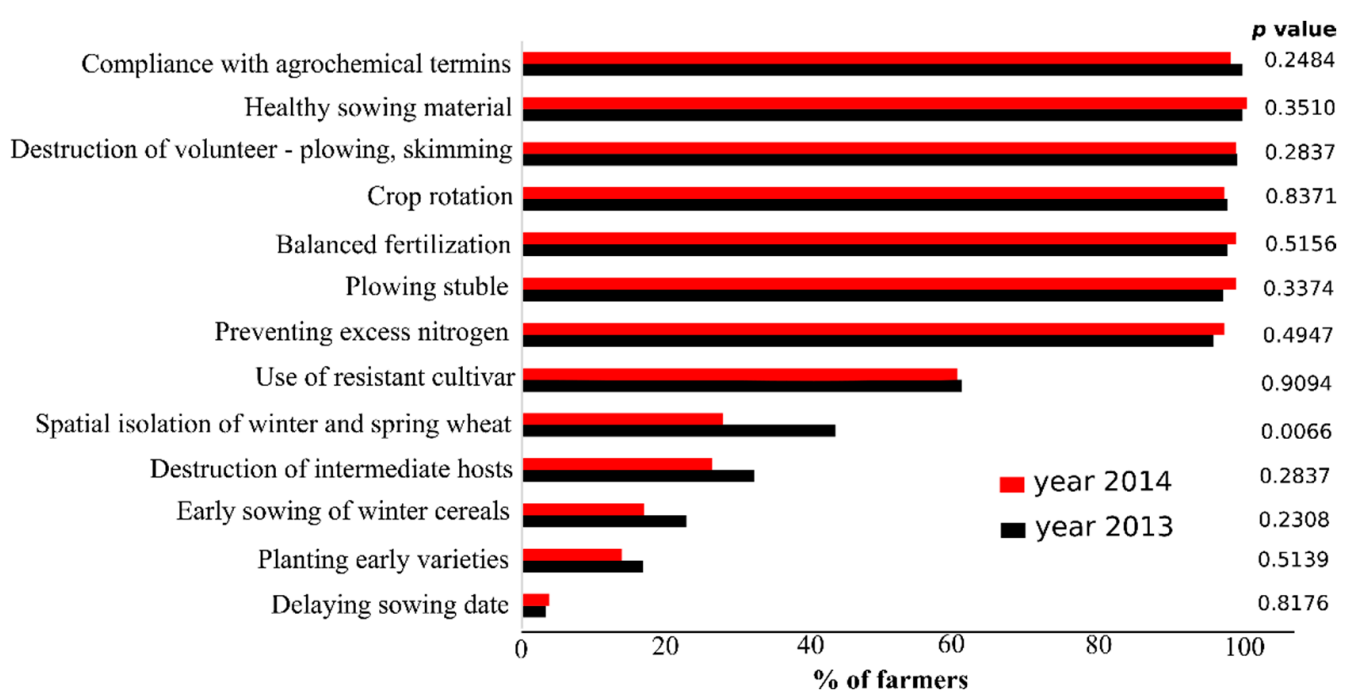

Figure 1. Non-chemical methods used by farmers before (2013) and after (2014) mandatory integrated pest management (IPM) implementation.

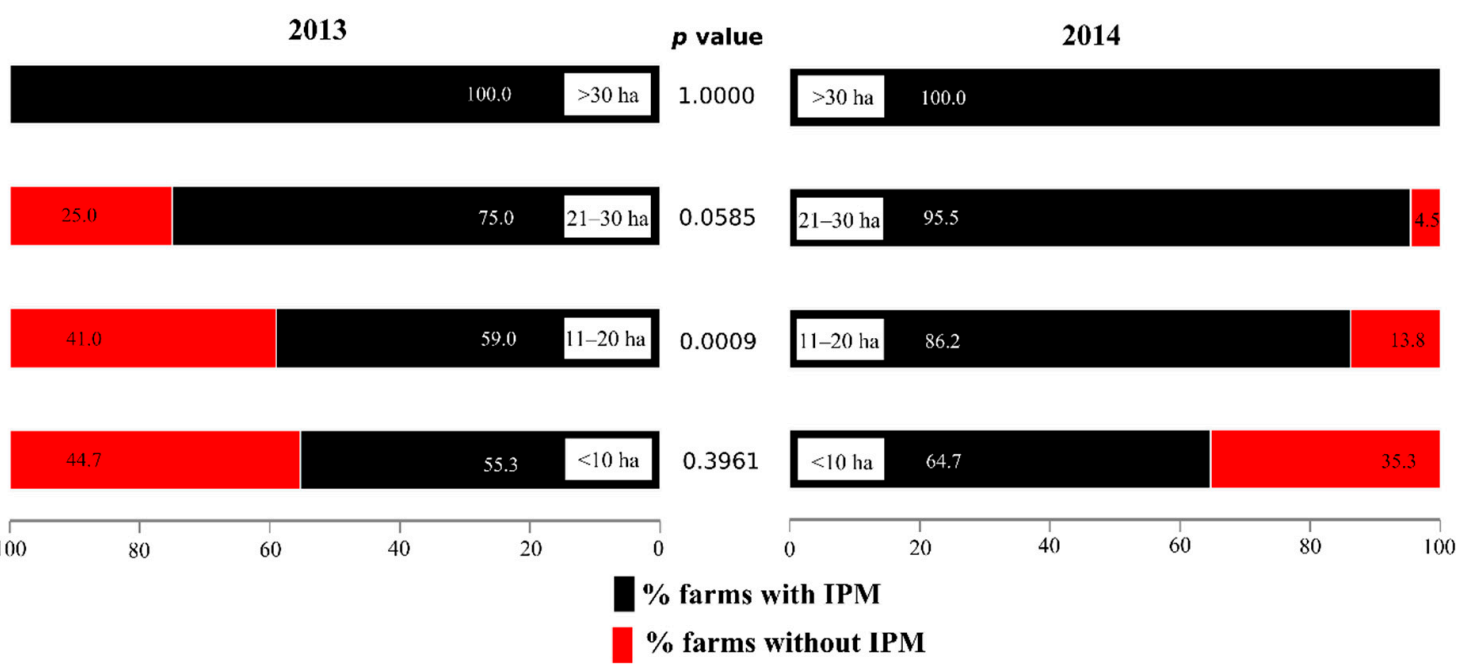

Figure 2. Application of integrated peat management (IPM) by farm size before (2013) and after (2014) mandatory IPM implementation.

Cereal crops were the main plant group in each farm group, regardless of the year or farm size. However, the proportion of cultivated cereals in each farm size group was higher in 2014 compared to 2013 (Figure 3). In 2014, the proportion of farms that cultivated root crops decreased in every farm size group though the tendency to cultivate root crops on the larger farms continued. The proportion of farms that cultivated other plants in 2013 was significantly higher than in 2014 in the two groups of farms: $>30$ ha and $<10$ ha.

In our questionnaire, farmers were asked to recognize the most common plant fungal diseases that affected grain production in Poland. Farmers' knowledge of the majority of plant fungal diseases had increased by the second year. Blumeria graminis, a fungus that causes powdery mildew on grasses [30-32], was the most successfully recognized disease (Figure 4). The recognizability of this fungus may be enhanced by the characteristic white bloom that appears on the leaves of plants and from the frequency of disease occurrence. Brown rust (Puccinia recondita) was ranked second; $65 \%$ of farmers were able to identify this disease in 2013 and 74.6\% in 2014. Eyespot (Oculimacula yallundae) was ranked third: $40 \%$ of farmers had knowledge of this disease in 2014-13\% higher than in the previous year. Knowledge of tan spot disease (Pyrenophora tritici-repentis) and fusarium ear blight (Fusarium spp.) had decreased by the second year. In 2013, 40.7\% of farmers were able to describe 
$\tan$ spot disease while in 2014 , only $32.3 \%$ were able to do so. Similarly, $22 \%$ of farmers were able to describe fusarium ear blight in 2013 and only $14.6 \%$ in 2014. Less than $20 \%$ of farmers demonstrated knowledge of snow mold disease (Microdochium nivale) and the other grain crop diseases.

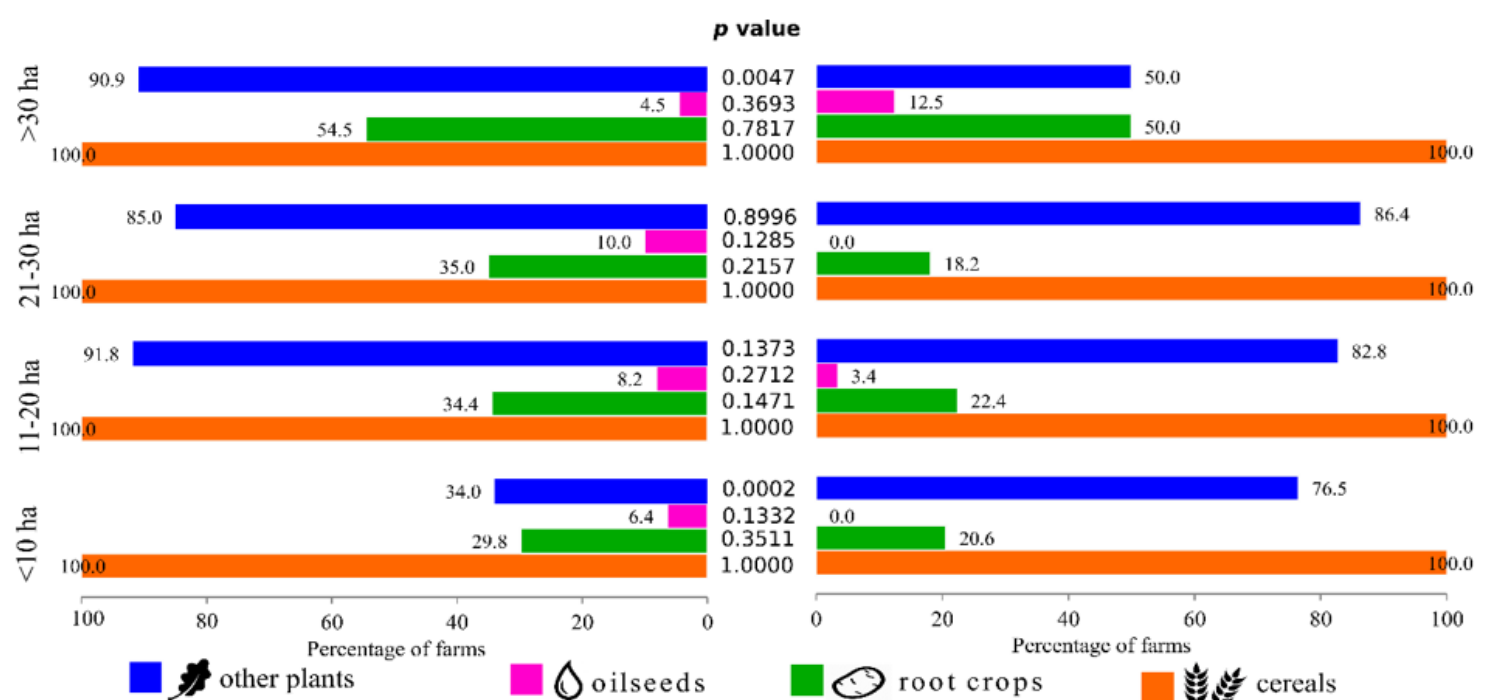

Figure 3. Cultivated crops before (2013) and after (2014) mandatory integrated pest management (IPM) implementation.

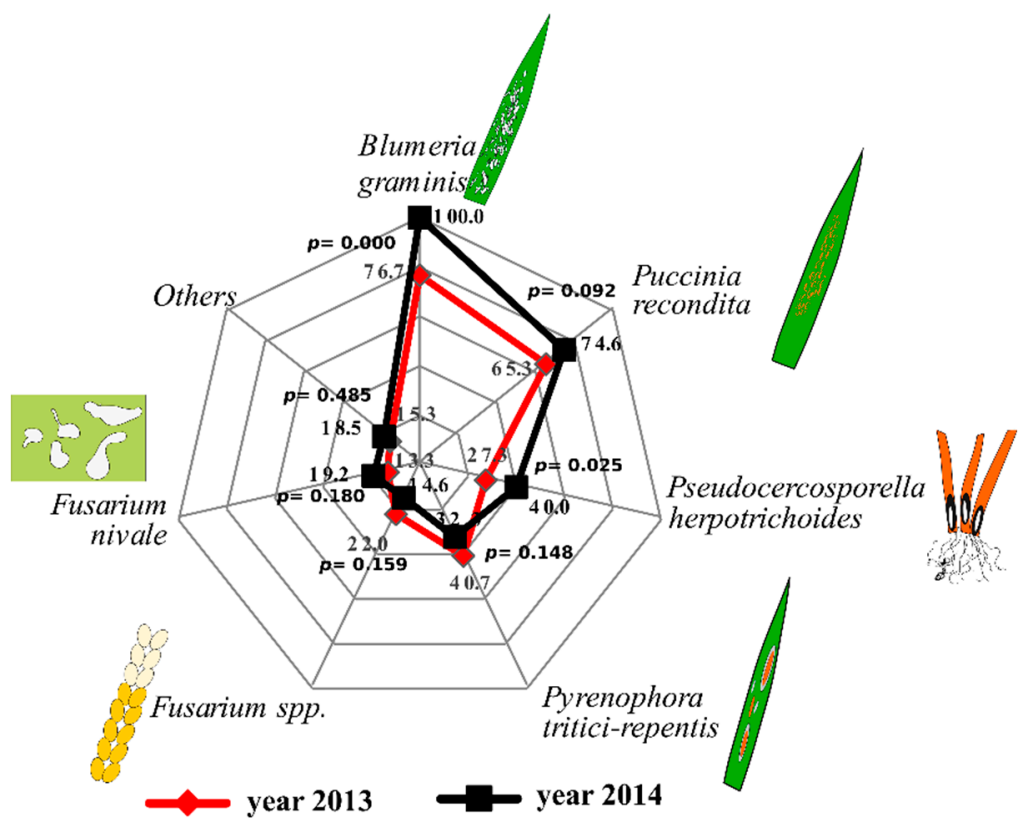

Figure 4. Farmers' knowledge of plant diseases before (2013) and after (2014) mandatory integrated peat management (IPM) implementation.

We closely examined the ability of farmers to recognize powdery mildew, brown rust and eyespot (Figure 5). We observed that as farm size increased, so did farmers' knowledge of crop diseases. In $2013,76.6 \%, 85 \%$ and $100 \%$ of farmers with farm size $<10,21-30$ and $>30$ ha respectively, were knowledgeable of powdery mildew. In $2014,70.6 \%, 77.3 \%$ and $81.3 \%$ of farmers with farm size $<10$, 21-30 and $>30$ ha respectively, were knowledgeable of brown rust.

As farm size increased, the proportion of farmers using foliage protection was also higher; $100 \%$ of farms > 10 ha used a seed dressing in 2013. In 2014, we observed an increase in the use of fungicide 
concomitant with increased farm area; there was a strong correlation of over 0.5 for both years and for the two techniques (Figure 6).

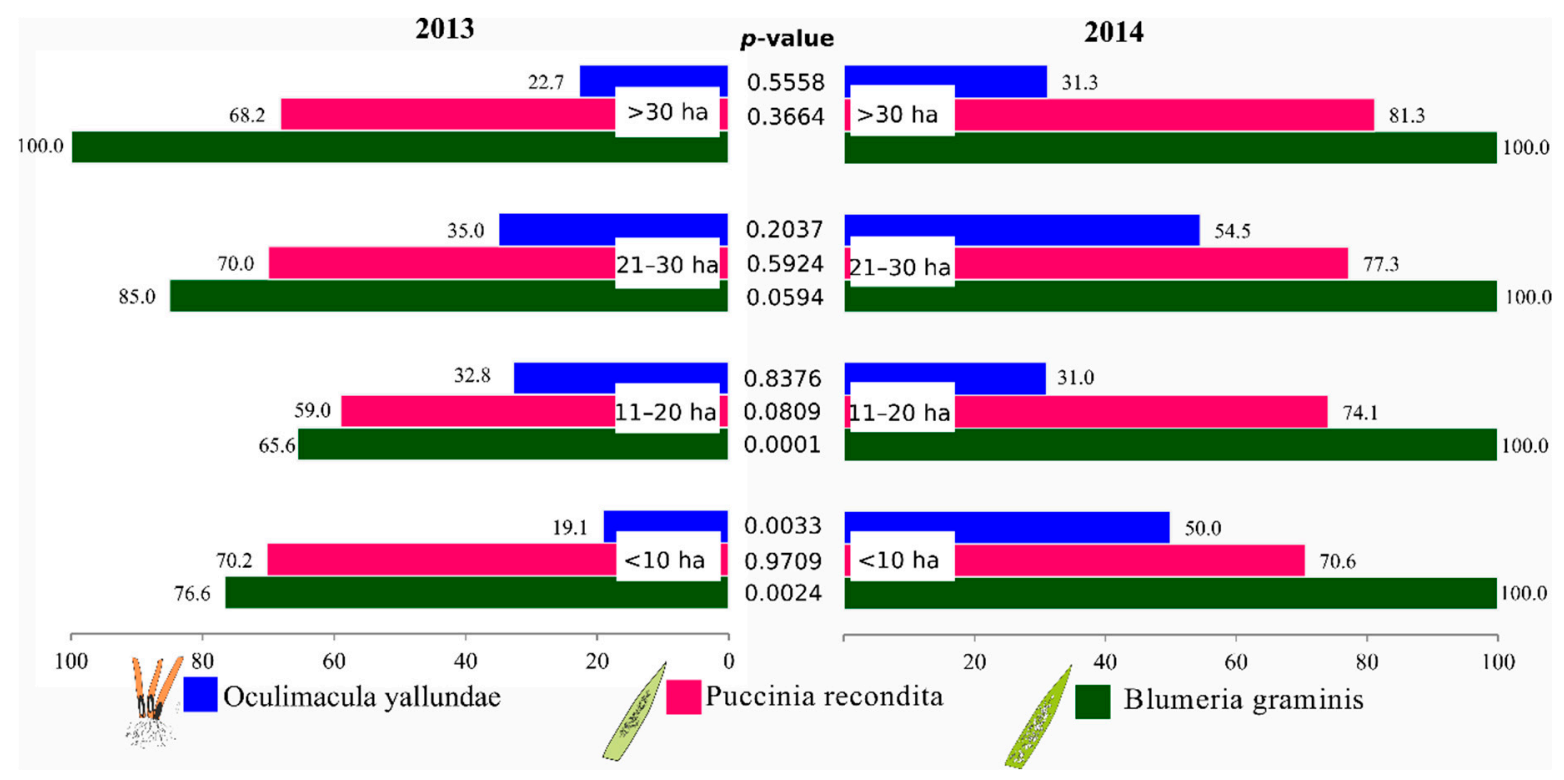

Figure 5. Diagnosis of the three most common fungal diseases identified by farmers before (2013) and after (2014) mandatory integrated peat management (IPM) implementation.

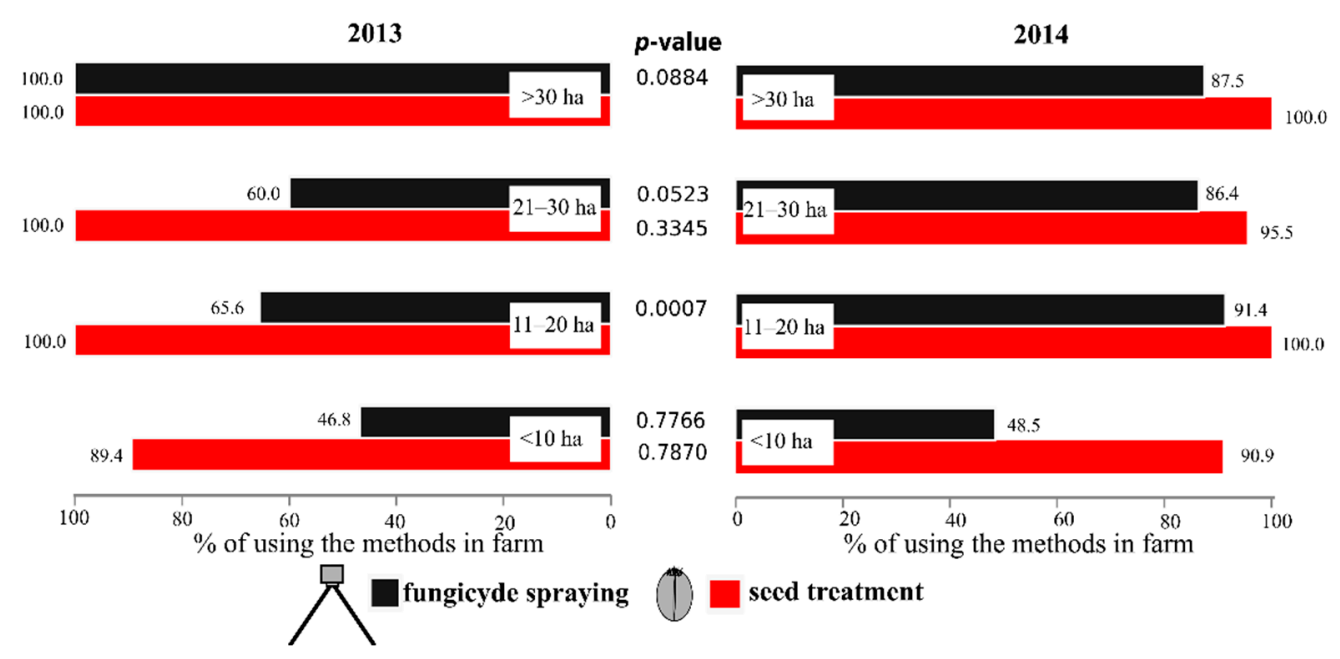

Figure 6. Types of chemical plant protection used by farmers before (2013) and after (2014) mandatory integrated peat management (IPM) implementation.

Chemical control was the most common method of protection used by the farmers (Figure 7). In both years, all the surveyed farmers used chemical methods for plant protection regardless of the area under cultivation. From among non-chemical methods, farmers chose the agro-technical method combined with the cultivation method more often than the agro-technical method alone. In 2013, farmers with farms $>20$ ha selected the combination of those two methods more often, while farmers with smaller farms selected only the agro-technical method. 

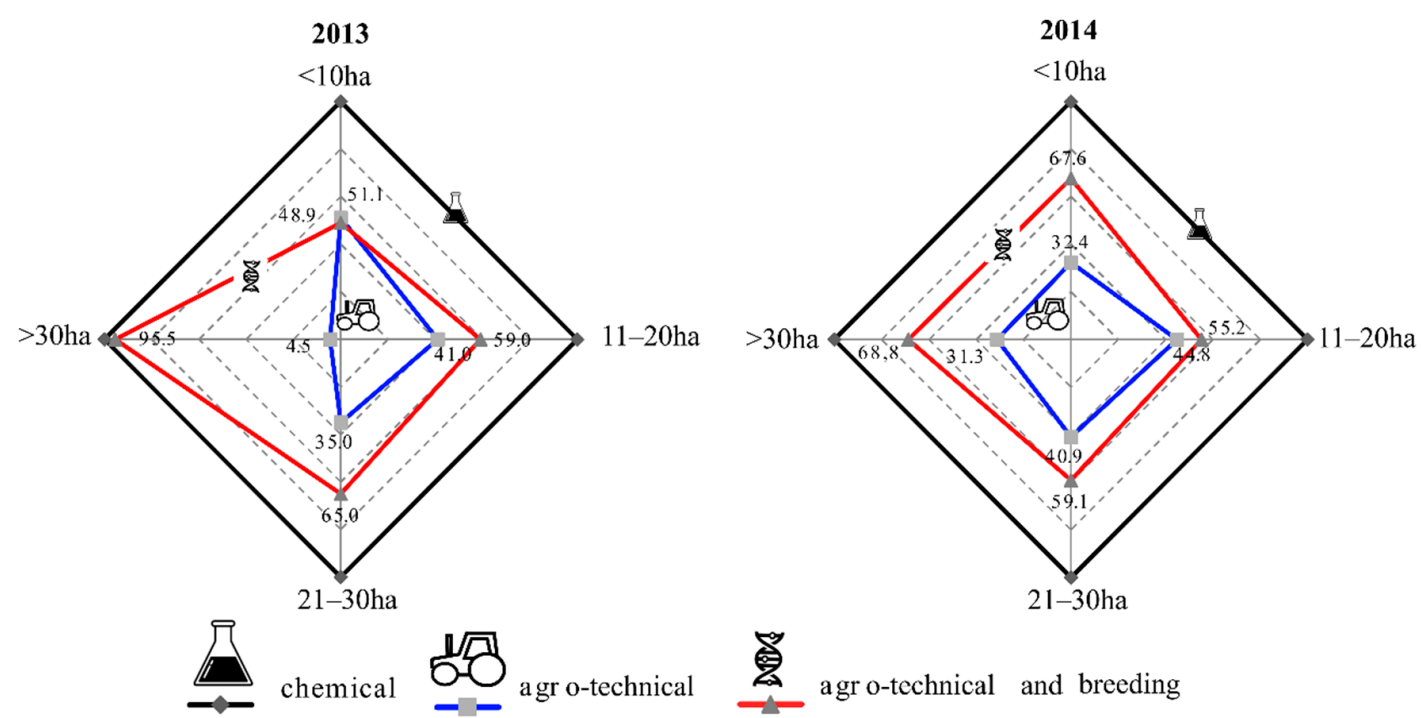

Figure 7. Pest management method used by farmers before (2013) and after (2014) mandatory integrated peat management (IPM) implementation.

\section{Discussion}

To ensure that the effects of IPM implementation are successfully achieved, it is essential that the knowledge of IPM is expanded and that the decisions that farmers make with regard to plant protection are supported. Knowledge is the key to achieving the same level of crop yields with reduced use of chemical plant protection products [33]. In Poland, their usage exceeded $1.1 \mathrm{~kg}$ per ha in 2001-2012 - a figure that was less than $50 \%$ of the European average $(2.78 \mathrm{~kg})$. Poland consumes less plant protection products than France, Germany or UK. Those most commonly applied are herbicides $(0.69 \mathrm{~kg})$, followed by fungicides $(0.37 \mathrm{~kg})$ and insecticides $(0.06 \mathrm{~kg})$. Poland is still a developing country and for this reason, the demand for chemicals in agriculture will continue to grow. At the same time, there is debate in the international arena over the withdrawal of a large number of active substances. Depending on the crop and cultivation technology, this withdrawal may result in increased production costs (some active substances will not be permitted by law in the future, therefore, the production costs may increase) and decreased quality and quantity of yield [17]. Golinowska et al. [34] analyzed the costs of large-scale farms in 2006-2012 and noted that the use of plant protection products (in kilograms of active ingredient per ha) increased for each of the crops grown on the farm. For wheat, the use increased from $1.6 \mathrm{~kg} \mathrm{ha}^{-1}$ in 2006 to $2.28 \mathrm{~kg} \mathrm{ha}^{-1}$ in 2012, and for oilseed rape, it increased from $1.8 \mathrm{~kg} \mathrm{ha}^{-1}$ in 2006 to $2.46 \mathrm{~kg} \mathrm{ha}^{-1}$ in 2012. During our study period, the number of treatments increased from three to six in the case of wheat, and from five to ten for oilseed rape. Despite the use of a growing number of plant protection methods and increased number of treatments, the unit cost of plant protection products per hectare showed a downward trend. In surveys conducted in California [35], strong correlations between the use of IPM practices and farmers age, education and household size were found. Farm income, the type of land ownership and farming experience did not affect the answers provided by the respondents. Young farmers under 50 years of age were more willing to implement IPM practices but awareness of IPM increased in conjunction with higher levels of education. The size of farm determined how IPM practices were implemented. Work by Shennan et al. [35] showed that IPM was extensively used on farms $<4$ ha and on farms $>400$ ha, but was used least often on farms $4-40$ ha in size. Similar results were obtained in our study, which showed that the use of IPM practices in Poland takes place mainly on the larger farms. Furthermore, farmers' awareness of plant fungal diseases and the use of non-chemical methods of plant protection were significantly greater in the larger farms. In contrast, Kruszyński et al. [36] reported that only $34 \%$ of farmers were able to give a definition of integrated plant protection. Their study also indicated that IPM knowledge among farmers was dependent on the size of the farm but in contrast to our study, they 
reported that farmers with larger farms had a lower knowledge of IPM. Education level of the farmers was positively correlated with their IPM knowledge: IPM awareness increased at higher education levels. Research by Kruszyński et al. [36] showed that the majority of agricultural producers had a negative attitude towards the use of IPM on their farms.

Income from agricultural production is critically dependent on the price of agricultural products. When prices are persistently high, farmers use more fungicides to achieve and maintain high crop yields. When prices drop, farmers use a reduced volume of plant protection products and thus, crop yields automatically decrease. Agricultural product prices are an important factor influencing the actions of farmers [37]. In 2013, wheat prices were very high at $€ 250$ per ton of grain (WGT 2016) and the large accrued profits encouraged farmers to invest in fungicides in the following year while simultaneously increasing their knowledge of the common diseases of the crop. In our study period, there was a significant increase in the knowledge levels of the diseases that occur during the cultivation of cereals. Weather during the growing season has a decisive influence on the development of fungal diseases, and can be very diverse in subsequent years, determining the occurrence of various diseases with different intensities [38]. The year 2013 was conducive to the development of fungal diseases in cereals; rainfall and high temperatures in May contributed to the development of most pathogens. In this study, some farmers did not appear to have substantial knowledge of the fungal crop diseases that may appear during crop growth, despite the critical impact that these diseases have on the quantity and quality of the crop yield. Powdery mildew disease was the only disease that farmers were able to diagnose $100 \%$ in both years of the study.

One approach to prevent the occurrence of disease in cereals is the use of non-chemical methods. These include crop rotation, compliance with deadlines for agronomic crop cultivation and sowing, as well as sowing healthy seeds [39]. In the surveyed farms, compliance with agronomic deadlines, healthy seed sowing, destruction of volunteer plants, balanced fertilization applications and the prevention of excessive nutrient loading (particularly nitrogen) were the most frequently chosen methods. To a lesser extent, farmers benefited from solutions such as the delay in sowing, destruction of intermediate hosts or the use of resistant cultivars. Larger farms usually focus on the production of high-quality materials, use modern techniques to protect plants, and thus use more active substances compared to smaller farms. In Poland, a large proportion of crop market is taken by grain, including wheat, which makes it difficult or impossible to implement a suitable crop rotation in practice.

Farmers of smaller farms often do not have sufficient crop protection knowledge and, therefore, use fewer pesticides. In contrast, larger producers are sufficiently knowledgeable of plant protection products and are generally well educated. At the same time, these farms use more pesticides [40]. Surveys have confirmed this trend; awareness of farmers of IPM methods and their usage rises in conjunction with increased farm area. Nave et al. [41] described three plant protection strategies that farmers generally apply. In the first strategy, producers restrict the use of plant protection products and at the same time, use practices that reduce pest pressure. This strategy allows farmers to achieve average profits (gross margin), but are profitable when direct payments are taken into account. In the second strategy, farmers use the average number of plant protection products and have the highest rate of economic returns. Regardless of the price of wheat, they achieve the best economic results. In the third strategy, farmers use intensive crop protection to achieve high crop yields. Differentiation in the system of plant protection depends not only on economic factors but is also strongly related to the farmers' environment and motivation. The producers that utilize the third strategy are the least concerned about the public opinion and they need to reduce the use of chemical plant protection products. The amount of plant protection products used, and the method employed were not dependent on the size of the farm. Instead, the relationship was determined by the motivation of the farmer; those who had children and were also landowners, tended to be more concerned about the future and, as such, used a smaller amount of chemical products.

Research examining the economic aspect of the application of IPM practices mainly focuses on the analysis of the budget allocated to the pesticides used without taking into account other factors. 
In the US, farmers who chose to voluntarily use IPM techniques were less risk-sensitive. Among them, those with large irrigated farms and using their own family as employees constituted a larger share. In addition, local conditions and cultivated plants [42] had an impact on the use of IPM. Similar conclusions were also drawn from studies carried out on coffee farmers in Colombia. On the other hand, the authors of other studies report that the size of the farm does not affect the practices adopted by farmers and it may be influenced by experience and scale of production, which nevertheless often translates into the size of the farm [43].

Farmers derive their knowledge of crop production from different sources [44]. Agricultural advisors play a major role. The more factors involved in agricultural activities, the greater the chance that they will implement the action deliberately. To increase the correct application of IPM techniques, more attention should be devoted to the form in which farmers would like to receive knowledge about selected issues, courses and methods of their training. Their current practice should also be taken into account when indicating possible changes [45]. Plant protection product labels, the seller of the plant protection products and external consulting firms also play important roles. Depending on the knowledge sources that farmers consult, their opinion of environmental protection and the negative consequences associated with the use of plant protection products are shaped differently [46]. In many cases, the farmers do not understand the risks associated with the use of plant protection products [47]. This is confirmed by the results of our research, in which farmers' awareness of crop disease is low. This demonstrates a lack of ability to use economic injury threshold levels, which are the basis for the use of IPM. However, there is a trend of increasing awareness by producers in this field. Farmers' decisions are often based on scientific knowledge but also on the experience and knowledge gained in crop cultivation under specific conditions [48].

On the one hand, the farmer is obliged to use Integrated Plant Protection under which non-chemical methods should be chosen first, while the control system focuses exclusively on the correct use of chemical methods. In addition, the control system is mainly oriented to verify the documentation kept by the farmers-it does not check such elements as correct crop rotation or for use of resistant varieties. While using chemical plant protection products, the farmer must somehow prove the need for application and then provide the effectiveness of the treatment.

Advisors and knowledge disseminators play a big role in this. They should know the local environment well and be able to interact with farmers. An in-depth understanding of culture and values is essential if teaching is to succeed. Only then can the farmers successfully learn and practice IPM [49]. Recommended methods of information transfer should be a combination of radio and television programs [50].

Author Contributions: Investigation, Z.S., S.Ś., R.G.-W. and P.Ł.K.; methodology, Z.S., S.Ś., R.G.-W.; writingoriginal draft, Z.S., S.Ś. and P.Ł.K.; writing—review draft, S.Ś. All authors have read and agreed to the published version of the manuscript.

Funding: This research received no external funding.

Acknowledgments: The paper was financed within the framework of Ministry of Science and Higher Education programme 'Regional Initiative of Excellence' in years 2019-2022, Project No. 005/RID/2018/19.

Conflicts of Interest: The authors declare no conflict of interest.

\section{References}

1. E Ehler, L. Integrated pest management (IPM): Definition, historical development and implementation, and the other IPM. Pest Manag. Sci. 2006, 62, 787-789. [CrossRef]

2. Erbaugh, M.; Kibwika, P.; Donnermeyer, J. Assessing Extension Agent Knowledge and Training Needs to Improve IPM Dissemination in Uganda. J. Int. Agric. Ext. Educ. 2007, 14, 14. [CrossRef]

3. Ziska, L.H.; Bradley, B.A.; Wallace, R.D.; Bargeron, C.T.; Laforest, J.H.; Choudhury, R.A.; Garrett, K.A.; Vega, F.E. Climate Change, Carbon Dioxide, and Pest Biology, Managing the Future: Coffee as a Case Study. Agronomy 2018, 8, 152. [CrossRef] 
4. Sawinska, Z.; Strzelinska, J.; Switek, S.; Glowicka-Woloszyn, R. Integrated pest management (IPM) still not sufficiently used in practice. Phytopathology 2018, 108. Available online: https://apsjournals.apsnet.org/doi/ pdf/10.1094/PHYTO-108-10-S1.240 (accessed on 3 February 2020).

5. Thresher, R.E.; Hayes, K.; Bax, N.J.; Teem, J.; Benfey, T.J.; Gould, F. Genetic control of invasive fish: Technological options and its role in integrated pest management. Biol. Invasions 2014, 16, 1201-1216. [CrossRef]

6. Parsa, S.; Morse, S.; Bonifacio, A.; Chancellor, T.C.B.; Condori, B.; Crespo-Pérez, V.; Hobbs, S.L.A.; Kroschel, J.; Ba, M.N.; Rebaudo, F.; et al. Obstacles to integrated pest management adoption in developing countries. Proc. Natl. Acad. Sci. USA 2014, 111, 3889-3894. [CrossRef] [PubMed]

7. Zalucki, M.P.; Adamson, D.; Furlong, M.J. The future of IPM: Whither or wither? Aust. J. Èntomol. 2009, 48, 85-96. [CrossRef]

8. Meissle, M.; Mouron, P.; Musa, T.; Bigler, F.; Pons, X.; Vasileiadis, V.P.; Otto, S.; Antichi, D.; Kiss, J.; Pálinkás, Z.; et al. Pests, pesticide use and alternative options in European maize production: Current status and future prospects. J. Appl. Èntomol. 2009, 134, 357-375. [CrossRef]

9. Świtek, S.; Sawinska, Z. Farmer rationality and the adoption of greening practices in Poland. Sci. Agricola 2017, 74, 275-284. [CrossRef]

10. Ruiu, L. Microbial Biopesticides in Agroecosystems. Agronomy 2018, 8, 235. [CrossRef]

11. Directive 2009/128/EC of the European Parliament and of the Council of 21 October 2009 Establishing a Framework for Community Action to Achieve the Sustainable use of Pesticides. Available online: https://eurlex.europa.eu/LexUriServ/LexUriServ.do?uri=OJ:L:2009:309:0071:0086:en:PDF (accessed on 3 February 2020).

12. C/2017/8878 Commission Implementing Regulation (EU) 2017/2470 of 20 December 2017 Establishing the Union List of Novel Foods in Accordance with Regulation (EU) 2015/2283 of the European Parliament and of the Council on Novel Foods. Available online: https:/eur-lex.europa.eu/legal-content/EN/TXT/?uri= CELEX\%3A32017R2470 (accessed on 3 February 2020).

13. European Commission Sustainable Use Pesticide. Available online: https://ec.europa.eu/food/plant/ pesticides/sustainable_use_pesticides/ipm_en (accessed on 20 December 2019).

14. Rozporządzenie Ministra Rolnictwa i Rozwoju Wsi z dnia 18 kwietnia 2013 r. w sprawie wymagań integrowanej ochrony roślin. Available online: http://prawo.sejm.gov.pl/isap.nsf/DocDetails.xsp?id= WDU20130000505 (accessed on 3 February 2020).

15. Rozporządzenie Ministra Rolnictwa i Rozwoju Wsi z dnia 8 maja 2013 r. w sprawie szkoleń z zakresu środków ochrony roślin. Available online: http://prawo.sejm.gov.pl/isap.nsf/DocDetails.xsp?id=WDU20130000554 (accessed on 3 February 2020).

16. Wymagania dla stosujących środki ochrony roślin. Available online: http://piorin.gov.pl/srodki-ochronyroslin/wym-dla-stosujacych-sor (accessed on 29 January 2020).

17. Obwieszczenie ministra rolnictwa i rozwoju wsi z dnia 6 maja 2013 r. w sprawie krajowego planu działania na rzecz ograniczenia ryzyka związanego ze stosowaniem środków ochrony roślin. Available online: http://prawo.sejm.gov.pl/isap.nsf/DocDetails.xsp?id=WMP20130000536 (accessed on 3 February 2020).

18. Świadczenie usług doradczych w ramach PROGRAMU ROZWOJU OBSZARÓW WIEJSKICH $2014-2020$. Available online: https://www.cdr.gov.pl/informacje-branzowe/uslugi-doradcze-prow-2014-2020 (accessed on 3 February 2020).

19. Bryła, M.; Waśkiewicz, A.; Podolska, G.; Szymczyk, K.; Jędrzejczak, R.; Damaziak, K.; Sułek, A. Occurrence of 26 Mycotoxins in the Grain of Cereals Cultivated in Poland. Toxins 2016, 8, 160. [CrossRef] [PubMed]

20. Kanianska, R. Agriculture and Its Impact on Land-Use, Environment, and Ecosystem Services. In Landscape Ecology_The Influences of Land Use and Anthropogenic Impacts of Landscape Creation; IntechOpen: London, UK, 2016.

21. Birch, A.N.E.; Begg, G.S.; Squire, G.R. How agro-ecological research helps to address food security issues under new IPM and pesticide reduction policies for global crop production systems. J. Exp. Bot. 2011, 62, 3251-3261. [CrossRef] [PubMed]

22. Lamichhane, J.R.; Dachbrodt-Saaydeh, S.; Kudsk, P.; Messéan, A. Towards a reduced reliance on conventional pesticides in European agriculture. Plant Dis. 2016, 100, 10-24. [CrossRef] [PubMed]

23. Barzman, M.; Bàrberi, P.; Birch, A.N.E.; Boonekamp, P.; Dachbrodt-Saaydeh, S.; Graf, B.; Hommel, B.; Jensen, J.E.; Kiss, J.; Kudsk, P.; et al. Eight principles of integrated pest management. Agron. Sustain. Dev. 2015, 35, 1199-1215. [CrossRef] 
24. Sadighi, H.; Roosta, K. Assessing farmers' sustainable agricultural practice needs: The case of corn growers in fars, Iran. J. Agric. Sci. Technol. 2002, 4, 103-110.

25. Walczak, F. Agrophages monitoring in agricultural integrated plant protection. Fragm. Agron. 2010, 27, 147-154.

26. Nowak, M.M. Resource Base of the Dairy Industry in a Regional Frame. Rocz. Nauk. Stowarzyszenia Ekon. Rol. i Agrobiznesu 2016, 18, 189-194.

27. Poczta, W.; Bartkowiak, N. Regional Differentiation of Agriculture in Poland. J. Agribus. Rural Dev. 2012, 1, 95-109.

28. Produkcja upraw rolnych i ogrodniczych w 2016 roku. Available online: https://stat.gov.pl/obszarytematyczne/rolnictwo-lesnictwo/uprawy-rolne-i-ogrodnicze/produkcja-upraw-rolnych-i-ogrodniczychw-2016-roku, 9,15.html (accessed on 27 January 2020).

29. The Characteristics of Agricultural Holdings in Wielkopolskie Voivodship. Available online: https://poznan. stat.gov.pl/ (accessed on 29 January 2020).

30. Menardo, F.; Praz, C.R.; Wicker, T.; Keller, B. Rapid turnover of effectors in grass powdery mildew (Blumeria graminis). BMC Evol. Boil. 2017, 17, 223. [CrossRef]

31. Tomkowiak, A.; Skowrońska, R.; Buda, A.; Kurasiak-Popowska, D.; Nawracała, J.; Kowalczewski, P.Ł.; Pluta, M.; Radzikowska, D. Identification of Leaf Rust Resistance Genes in Selected Wheat Cultivars and Development of Multiplex PCR. Open Life Sci. 2019, 14, 327-334.

32. Tomkowiak, A.; Skowrońska, R.; Weigt, D.; Kwiatek, M.; Nawracała, J.; Kowalczewski, P.Ł.; Pluta, M. Identification of Powdery Mildew Blumeria graminis f. sp. tritici Resistance Genes in Selected Wheat Varieties and Development of Multiplex PCR. Open Chem. 2019, 17, 157-165. [CrossRef]

33. David, S.; Asamoah, C. Farmer knowledge as an early indicator of IPM adoption: A case study from cocoa farmer field schools in Ghana. J. Sustain. Dev. Afr. 2011, 13, 213-224.

34. Golinowska, M.; Kruszyński, M.; Bogacz, M. Costs of integrated plant protection in large-scale farms in 2006-2012. Prog. Plant Prot. 2013, 53, 240-246.

35. Shennan, C. Profiles of California farmers by degree of IPM use as indicated by self-descriptions in a phone survey. Agric. Ecosyst. Environ. 2001, 84, 267-275. [CrossRef]

36. Kruszyński, M.; Golinowska, M.; Borkowska, M.; Wiciak, T. Pro-environmental awareness of agricultural producers and integrated pest management in Poland. Prog. Plant Prot. 2015, 55, 114-118. [CrossRef]

37. Liu, X.; Lehtonen, H.; Purola, T.; Pavlova, Y.; Rötter, R.; Palosuo, T. Dynamic economic modelling of crop rotations with farm management practices under future pest pressure. Agric. Syst. 2016, 144, 65-76. [CrossRef]

38. Kurowski, T.P.; Marks, M.; Makowski, P.; Jaźwińska, E. Health status of winter wheat depending on the two years method of lying the land fallow. Fragm. Agron. 2009, 26, 102-108.

39. El Khoury, W.; Makkouk, K. Integrated Plant Disease Management in Developing Countries. J. Plant Pathol. 2010, 92, 35-42. [CrossRef]

40. Matyjaszczyk, E. Plant protection in Poland on the eve of obligatory integrated pest management implementation. Pest Manag. Sci. 2013, 69, 991-995. [CrossRef]

41. Nave, S.; Jacquet, F.; Jeuffroy, M.-H. Why wheat farmers could reduce chemical inputs: Evidence from social, economic, and agronomic analysis. Agron. Sustain. Dev. 2013, 33, 795-807. [CrossRef]

42. Fernandez-Cornejo, J.; Beach, E.D.; Huang, W.-Y. The Adoption of IPM Techniques By Vegetable Growers in Florida, Michigan and Texas. J. Agric. Appl. Econ. 1994, 26, 158-172. [CrossRef]

43. Blake, G.; Sandler, H.; Coli, W.; Pober, D.; Coggins, C. An assessment of grower perceptions and factors influencing adoption of IPM in commercial cranberry production. Renew. Agric. Food Syst. 2007, 22, 134-144. [CrossRef]

44. Kilpatrick, S.; Johns, S. How farmers learn: Different approaches to change. J. Agric. Educ. Ext. 2003, 9, 151-164. [CrossRef]

45. Samiee, A.; Rezvanfar, A.; Faham, E. Factors influencing the adoption of integrated pest management (IPM) by wheat growers in Varamin County, Iran. Afr. J. Agric. Res. 2009, 4, 491-497.

46. Lichtenberg, E.; Zimmerman, R. Information and farmers' attitudes about pesticides, water quality, and related environmental effects. Agric. Ecosyst. Environ. 1999, 73, 227-236. [CrossRef] 
47. Calliera, M.; Berta, F.; Galassi, T.; Mazzini, F.; Rossi, R.; Bassi, R.; Meriggi, P.; Bernard, A.; Marchis, A.; Di Guardo, A.; et al. Enhance knowledge on sustainable use of plant protection products within the framework of the Sustainable Use Directive. Pest Manag. Sci. 2013, 69, 883-888. [CrossRef]

48. Ilbery, B.; Maye, D.; Little, R. Plant disease risk and grower-agronomist perceptions and relationships: An analysis of the UK potato and wheat sectors. Appl. Geogr. 2012, 34, 306-315. [CrossRef]

49. Palis, F.G. The role of culture in farmer learning and technology adoption: A case study of farmer field schools among rice farmers in central Luzon, Philippines. Agric. Hum. Values 2006, 23, 491-500. [CrossRef]

50. Pouratashi, M.; Iravani, H. Farmers' knowledge of integrated pest management and learning style preferences: Implications for information delivery. Int. J. Pest Manag. 2012, 58, 347-353. [CrossRef]

(C) 2020 by the authors. Licensee MDPI, Basel, Switzerland. This article is an open access article distributed under the terms and conditions of the Creative Commons Attribution (CC BY) license (http://creativecommons.org/licenses/by/4.0/). 